\author{
Muhammad Arshad \\ Doctor of Philosophy, Assistant Professor, Deanship of e-Learning and Information Technology \\ Jazan University, Jazan, Kingdom of Saudi Arabia \\ ORCID ID 0000-0003-2832-8705 \\ msarshad@jazanu.edu.sa
}

\title{
EXPERIENCE OF USING THE BLACKBOARD LEARNING MANAGEMENT SYSTEM IN JAZAN UNIVERSITY
}

\begin{abstract}
Students' engagement in a traditional classroom setting has been occurring for so long with several traditional tools such as textbooks, lectures, video, and group activities. Nowadays, globally and locally connected classes are the target of advanced education intellects. The Learning Management System (LMS) has become a basic tool for all institutions of advanced education, and the main thrust in web-based learning. The significance of the learning management system is defined by its role in building up instructive and educational development, so it is considered the most significant new tool for e-learning. As per a report by the Educause Research Center of U.S higher education institutions, almost $100 \%$ of advanced training institutions have an LMS setup, the LMS is utilized by $85 \%$ of faculty members, $56 \%$ of faculty use it daily, $83 \%$ of undergraduate and postgraduate students use the LMS and $56 \%$ say they use it in most or all courses. Learning Management System (LMS) is now not only becoming a critical tool for most higher education institutions but is also being seen as a driving force in online learning. Blackboard Learning Management System is a technologically improved learning platform within the context of the e-learning and aimed to investigate the use of Blackboard for training, learning, and examination purposes. In turn, this study is designed to explore the efficient utilization and evaluation of the students' academic performance and the use of a Learning Management System (LMS), Blackboard, among academics at Jazan University, Kingdom of Saudi Arabia. The primary aim of this research is to investigate how the faculty employs the features and communication tools in an online learning management system to facilitate the students in learning practice and to engage them in the material at hand. Through the findings obtained, both the faculty and the administrators are expectedly able to develop the online learning environment more effectively. It is also expected that the findings of this study can be a significant stimulus for other higher learning institutions in the Kingdom and the rest of the world to use the Blackboard for improved academic performance.
\end{abstract}

Keywords: e-Learning; learning management system; collaborative learning methods; Blackboard; Blackboard usage; faculty member; learning technologies for students; higher education institution.

\section{INTRODUCTION}

For a long time, educators have wanted to infuse new technologies into teaching and learning. Various paper, audio, visual, and electronic technologies have been introduced into learning and training over the years. Technological innovation has made the learning system more perfect and made teaching practice more developed. As the Internet became larger, the technologies of the Learning Management System (LMS) became popular, empowering teachers with no technical knowledge to provide instruction to students at a distance $[1,2]$.

Today's students (typically under the age of 25) are referred to as digital natives - these digital natives are inclined to interactive learning approaches involving, among others, the use of group discussions, case studies, field training, and simulation. On the other hand, many higher education institutions provide face-to-face lectures in a conventional and ongoing way by utilizing printed books [3]. To keep up with the technologically savvy students they serve, academic staff at higher education institutions need to change their approach to teaching. To achieve this, many tertiary institutions continue to invest in online learning technology $[4,5]$. 
The Jazan University understudy seems to be lagging behind at a time when almost all universities are heading towards e-learning and make comprehensive use of information and communication technology (ICT) in teaching and learning. With massive student enrolments and related large classes, access to education remains a challenge for many students amid the university's investment in a learning management system (LMS) like Blackboard. With such a huge investment of time and money to acquire and install LMS, Blackboard, it is important to understand how and to what extent this technology can be utilized, and to determine the academic performance of using Blackboard. For this reason, the proposed study is to investigate the utilization of Blackboard by the faculty and students of Arts and Humanities of Jazan University. Faculty members, among other various existing factors, are found to act as the key and crucial success factors or pillars for e-learning, and the integration of information and communication technology is also a major factor in the learning environment [6]. As the biggest nation on the Arabian Gulf, the Kingdom of Saudi Arabia has many advanced education colleges and universities. This new vision of the Kingdom has then made the nation's higher education requirements more challenging. The leaders of HEIs in response to this have replied positively to the development of world-class universities and higher education [7].

In [8] the author aims to determine whether Ghanaian students are happy with online "mass" learning in higher education institutions in Beijing, China. This research therefore used an online survey to analyze the level of satisfaction with online learning in higher education institutions and how Ghanaian students cope with these "new initiatives'. Research results [9] from this report suggest that, due to the COVID-19 pandemic, universities around the world are moving more and more towards online learning or e-learning. The findings also indicate that staff preparation, trust, student usability and inspiration play an important role in ICT integrated learning, in addition to resources. The research paper [10] dicussed the role of online learning, as well as a SWOC (Strengths, Weaknesses, Opportunities, and Challenges) study of e-learning modes during a crisis. This article also sheds some light on the rise of EdTech Start-ups during the time of pandemics and natural disasters and provides public institutions with ideas on how to cope with online learning problems. The author of [11] provides some expert insights into online learning-related pedagogical material awareness. The results point to the nature of learning tasks with unique features, the integration of three forms of presence (social, cognitive and facilitative) and the need to adapt the evaluation to the current conditions for learning.

The following sections will present an overview of the literature related to the Learning Management System and its effective role, real-world examples of Blackboard LMS in education, and finally formulate the objective of the study. The next sections describe the theoretical framework and methodology of the study. These sections will then be continued with the findings and discussion followed by a conclusion and prospects for future work.

\subsection{Learning Management System and its Effective Role}

The pattern in education in the last decade has been a step towards online learning and "blended" learning, which substitute face-to-face instruction components. Blended learning refers to a mix of online and face-to-face learning; blended instruction is designed with the use of a learning management system to facilitate teaching and learning [12, 13].

The implementation of learning management systems brought about a major change in e-learning in the late 1990s. Blackboard, Moodle, and WebCT are common examples of learning management systems that are intended to promote web-based learning. A learning management system (LMS) refers to a web-enabling software platform designed to ensure the efficient management and delivery of learning materials for students [14]. Learning 
management systems make use of the internet as a medium to enable students to access resources from anywhere and at any time, thus removing geographic and time constraints. This then places learning management systems at the forefront of e-learning initiatives in many higher education institutions [15]. An instructor with LMS can practice some effective learning aspects such as self-depended learning, students' communication skills, and collaborative learning that can be a reflection of the students' comprehension of the subject. Moreover, learning evaluation will be achieved by ensuring that the inputs received from participants are aligned with the objective of the use of LMS [16]. In this paper, the term LMS refers to the Blackboard Learn as provided by Jazan University. Blackboard is a pioneering organization in education technology that services higher education, K-12, industry and government customers worldwide. The Blackboard platform is one of the most commonly used instructional platforms that lead to blended learning internationally and specifically at Saudi Universities. Blackboard provides users with a forum for collaboration and content sharing as an influential online education with a larger institutional use [17].

The major question is "Why this kind of LMS was chosen". King Abdulaziz University initially launched an e-learning system in Saudi Arabia in 2006, using Blackboard as the primary LMS. Other universities seem to have taken King Abdulaziz University's example and are using Blackboard, these institutions tend to use profit-making or commercial LMSs because their original companies are configured and supervised [18]. The specific features of Blackboard LMS are: asynchronous classes, easy to use course navigation, icons which make it easy to differentiate subject styles, keep grades and assignments in one location, HTML quality course content that can be conveniently retrieved and displayed, multiple types of communications which make collaboration easier through group work and discussion of board posts, scheduling assignments, forums and class discussions, simplicity of use on different devices.

\subsection{Real World Examples of Blackboard LMS in Education}

Blackboard has become a common learning platform based on the learning needs of the learners. It is described as an online learning management system customized to online programs that enable students to learn from anywhere in the world at any time. This learning management system also provides teachers with a forum to share all instructional materials that students can navigate online in an attempt to strengthen their research and teaching processes.

The author of [19] aims to define the facets of the efficacy of learning management systems that have played a role in the development of education and upbringing processes, and outlines the concept of Learning Management Systems as well as its various types. The paper covers the changes encountered by the learning management system in the Arab world in general and in the Kingdom of Saudi Arabia in particular. Research [20] offers a quantitative review exploring the results of using Blackboard Learn as a case study for higher education students in Lesotho, using Botho University as a learning platform. A hybrid approach to the system has been adopted for the research. The findings showed that Blackboard had a positive effect on the students' success. The results demonstrate that Integrative and Dynamic Blackboards are more appropriate for raising students' academic success at all stages. The research [21] was conducted to investigate the use of Blackboard by faculty members in the Colleges of Applied Sciences in the Sultanate of Oman and the factors affecting its use. This study is also part of a larger research initiative that examines multiple facets of Blackboard incorporation into the College. High-order functions of Blackboard such as Blog, discussion boards and virtual classroom are rarely used. The author of [22] examined the qualitative analysis to consider the effect on the output of students by using Blackboard in 
accounting courses. This target raised serious research concerns. Interview data from accounting students were gathered to answer the questions. The materials were analyzed using content analysis, which included reading them and searching for trends and patterns. The author decided which categories arose spontaneously from the results, compared them to our conceptual framework, and then came to a conclusion.

There are 28 public universities in Saudi Arabia and Blackboard is the most common system in public universities, as it is used by 25 universities, which accounts for $89 \%$ of the total. This is accompanied by Moodle, used by two universities, and is $7 \%$. The majority of the universities use D2L, which is just 4\%. The Canvas LMS has not yet been seen in Saudi Arabia. According to recent reports, Blackboard LMS outperforms other LMSs in Saudi public universities [23].

\subsection{Objective of the Study}

The primary objective of this study is to examine the use of Blackboard by faculty members and the effect of Blackboard on the academic success of students at Jazan University, KSA. The research questions of this study are:

- To what extent do faculty members at the Faculty of Arts and Humanities use Blackboard in their education?

- Are there some effects of demographic variables on the use of Blackboard by faculty members, including gender, age group, professional experience, and computer literacy?

- What is the effect of Blackboard on student academic performance?

- Does using Blackboard inspire students to be constructivists in knowledge building?

\section{THEORETICAL FRAMEWORK}

Using Blackboard technology to promote teaching and learning is part of innovative initiatives to educate people. This is why this study uses the philosophy of imagination as a scientific basis. We recognize the use of Blackboard as an innovative approach that can be tailored to affect the academic success of students. The use of Blackboard will inspire learners in their classrooms to be more imaginative. In reality, creativity theory is focused on creative psychology and people's thinking. The definition of innovation is also applied to creative education in information technology [24].

The Unified Theory of Acceptance and Use of Technology (UTAUT) model explains the users' intentions to use an information system and subsequent usage behavior [25]. UTAUT2 framework investigated the antecedents of LMS use from the students' perspective. This research demonstrated the void in the literature by omitting the construct of market value, and the construct of learning value was added to understand the perceived value of LMS [26]. Davis's technology acceptance model (TAM) is widely used in the Information System (IS) literature. TAM indicates that two factors determine the attitude, intention, and the actual use of an information system; these factors are perceived usefulness (PU) and perceived ease of use (PEOU). TAM implies that PU and PEOU, due to the use of the particular information system, are decided by external variables [27]. TAM2 model suggested that these external variables might be related to the subjective norm, image, job relevance, output quality, and result demonstrability. TAM2 provides common critical factors that might affect the PU and PEOU and consequently the actual use of an information system; however, these factors may not be the best fit for all systems including learning management systems [28]. 




Figure 1. Blackboard-Student-Performance Framework (24)

The goal of this research is to use qualitative and quantitative knowledge by endorsing the Blackboard-Student-Performance model to explore the relationship between the efficient utilization of Blackboard and students' academic performance. The various types of Blackboard that can be used are shown in Figure 1: Static Blackboard, Dynamic Blackboard, and Integrative Blackboard. Table 1 illustrates the taxonomy of the types of Blackboard in detail.

Table 1

\section{Taxonomy of Blackboard}

\begin{tabular}{|c|c|c|}
\hline Static Blackboard & Dynamic Blackboard & $\begin{array}{c}\text { Integrative } \\
\text { Blackboard }\end{array}$ \\
\hline $\begin{array}{c}\text { Used as informational } \\
\text { Blackboard }\end{array}$ & $\begin{array}{c}\text { Used as interactive } \\
\text { Blackboard }\end{array}$ & $\begin{array}{c}\text { Enables Blackboard to be } \\
\text { combined with other } \\
\text { external applications }\end{array}$ \\
\hline $\begin{array}{c}\text { Informs learners about } \\
\text { announcements of the } \\
\text { course }\end{array}$ & $\begin{array}{c}\text { Inclusive of Static } \\
\text { Blackboard functions }\end{array}$ & $\begin{array}{c}\text { Combines with other } \\
\text { software like Respondus } \\
\text { and Prometric test engines }\end{array}$ \\
\hline $\begin{array}{c}\text { Provides the students and } \\
\text { the teachers with many } \\
\text { tools }\end{array}$ & $\begin{array}{c}\text { Allows learner-instructor } \\
\text { interactions by live chat }\end{array}$ & $\begin{array}{c}\text { Allows students to take } \\
\text { exams and then } \\
\text { automatically grades them } \\
\text { by Blackboard }\end{array}$ \\
\hline $\begin{array}{c}\text { These tools are used for } \\
\text { announcements including } \\
\text { notifications, tasks, and } \\
\text { the calendar }\end{array}$ & $\begin{array}{c}\text { Interactions among peer-to- } \\
\text { peer through wikis, } \\
\text { discussion forums, and email }\end{array}$ & $\begin{array}{c}\text { Adobe Connect Professional } \\
\text { helps students to attend } \\
\text { online seminars in } \\
\text { synchronization }\end{array}$ \\
\hline $\begin{array}{c}\text { Tasks allow students to } \\
\text { organize according to the } \\
\text { subject or personal views }\end{array}$ & $\begin{array}{c}\text { Improves communication } \\
\text { through discussions and } \\
\text { virtual classroom }\end{array}$ & $\begin{array}{c}\text { Hybrid classroom sessions } \\
\text { are also supported, when } \\
\text { some learners are online and } \\
\text { several are on-campus. }\end{array}$ \\
\hline $\begin{array}{c}\text { Grade center provides } \\
\text { marks achieved in } \\
\text { assignments, test, and } \\
\text { quizzes }\end{array}$ & $\begin{array}{c}\text { It allows students to } \\
\text { download course materials } \\
\text { e.g. MP3, Video, PPT slides, } \\
\text { etc. }\end{array}$ & $\begin{array}{c}\text { Some limitations like } \\
\text { plagiarism, learner's } \\
\text { dedication, data security, } \\
\text { and confidentiality }\end{array}$ \\
\hline $\begin{array}{c}\text { Many services, including } \\
\text { and hyperlinks, are open } \\
\text { to teachers and students. }\end{array}$ & $\begin{array}{c}\text { Interactive blackboard is the } \\
\text { building block for } \\
\text { organizational skills and } \\
\text { modernist learners }\end{array}$ & $\begin{array}{c}\text { Protection of students in } \\
\text { their educational phase must } \\
\text { be critical when they are } \\
\text { interested in Blackboard }\end{array}$ \\
\hline
\end{tabular}


Many researchers have assessed student academic success using the final grades scored by GPAs (degree point averages) in the individual courses to classify students as those who perform well or not. This study will not use these quantitative or analytical data to assess the students' academic success. The author also used qualitative methods to demonstrate how Blackboard use would lead to passing or failing during the courses. Table 2 explains the assessment methods of students' academic performance.

Table 2

Students' Academic Performance Assessment Methods

\begin{tabular}{|c|c|}
\hline \multicolumn{2}{|c|}{ Assessment Methods of Students' } \\
\hline Traditional Assessment & Assessment by Blackboard \\
\hline Grade Point Averages (GPA) & Class Attendance Points \\
\hline Overall Semesters Percentage & Assignments, Tests, and Quizzes Marks \\
\hline Rank Position & Participation in Discussion and Forums \\
\hline Division & Final and Mid-Term Examination Marks \\
\hline
\end{tabular}

More precisely, the author follows the basic level of students' comprehension, the students' understanding of the difficulty levels of the tests, the students' enthusiasm in classes, the frequency of students requesting input in classes, and the extent of students' class involvement.

\section{METHODOLOGY}

The study aimed at exploring the use of Blackboard as a learning management system in undergraduate higher education programs. More precisely, the purpose of the study was to evaluate the impacts of Blackboard LMS integration on teaching and learning. This study is carried out using a mixed methodology with quantitative and qualitative approaches to accomplish the purpose of this study.

\subsection{Research Design}

The research methodology incorporates both quantitative and qualitative analysis that has been proved useful in gathering information of faculty members, students, and administration members.

\subsection{Sample Population}

Full-time faculty members and students of the Faculty of Arts and Humanities of Jazan University were the target population for this study. A total of 109 male and female faculty members and 80 students from the faculty were overviewed by daily progress reports of the courses' lectures and survey questionnaires respectively. The administartor examined and prepared the daily progress report of the courses' lectures. All students were asked to fill and submit the questionnaire. However, 13 cases have been identified as outliers and incomplete, so they have been excluded from the dataset to minimize inaccurate population inferences. Therefore, the actual sample of students was 67. To achieve the fundamental goal of the research, faculty members and students ought to be computer literate and have an Internet facility. 


\subsection{Data Collection}

Study design necessitates the evaluation of data from different sources in order to build a strong case. To this end, the data for this study was collected by making use of the daily progress report of courses' lectures and students' answers to the anonymous survey questionnaire.

Reports and analyses from LMS give a possibility to track learner interest, growth, and overall performance in e-Learning. Many Learning Management Systems have built-in reporting tools. Some even feature customizable LMS reports, in addition to their out-of-thebox options. However, the administrator examined and prepared the progress reports on the courses' lectures on a daily, weekly, and monthly basis for male and female groups of the semester courses. Microsoft Excel was used as a tool to create the progress report of courses' lectures and the parameters of this report are lecture-performance in terms of voice quality, completion rates, course contents, educational resources, and online assessment results.

Anonymous surveys are an appropriate method employed to collect exploratory, explanatory or descriptive types of data. Qualitative surveys are a type of data collection tool that is used to gather information about a sample population's experiences and meaningmaking processes in relation to a particular subject. The survey was carried out online. The questionnaire was posted online to 80 participating faculty students via the Blackboard system, which collected structured data through open-ended questions and Likert form alternative ordinate. The goal of the survey was to determine the efficacy of Blackboard features and components in improving the students' academic performance. The total survey responses were 67 , giving a $100 \%$ response.

\subsection{Data Validity and Reliability}

The nature of qualitative data does not lend itself to tightly packaged analysis as with quantitative data but is rather subject to the construction and interpretation of meaning on the part of the researcher and between the researcher and the research participants. The examination of Qualitative Information (QCA) was used to verify data obtained in the qualitative sense. Thematic content analysis is adopted for this study, as it is a validity assessment technique that can accommodate massive volumes of evidence. To assess the validity and constancy of the items used for the variables in the quantitative element, a reliability review was carried out. Cronbach's Alpha was used to conduct a reliability check on this [29].



Figure 2. Values of Cronbach's Alpha 
Cronbach's Alpha values ranging from 0.6 to 0.7 are known to be the lower level of tolerability for acceptability. Cronbach's Alpha higher than 0.7 shows that the variables are stable and the same homogeneity is calculated. These results show that the questionnaire is a reliable tool and can be utilized in this study because all Alpha scores are above 0.7 as illustrated in Figure 2.

\section{FINDINGS AND DISCUSSION}

This section introduces the findings of the research dependent on the gathered information to investigate the utilizing of Blackboard as a learning management system and its impact on students' academic performance at Jazan University, KSA.

\subsection{Demographic Analysis}

Demographic research requires items that help one to quantify societies' measurements and dynamics. These methods have primarily been developed to study human populations, but are extended to a variety of areas where researchers want to know how populations of social actors can change over time. Because of inequalities between faculty members in terms of ethnicity, age group, educational background, computer literacy, and internet access, it was expected that there would be certain discrepancies in the use of Blackboard.

\subsubsection{Gender}

Results presented in Figure 3 illustrate the use of Blackboard among male and female faculty members. It can be concluded that the use of technology overall is gender-specific, according to graph statistics the number of males using the technology is essentially higher than that of females; therefore there was an effect of gender on the use of Blackboard.

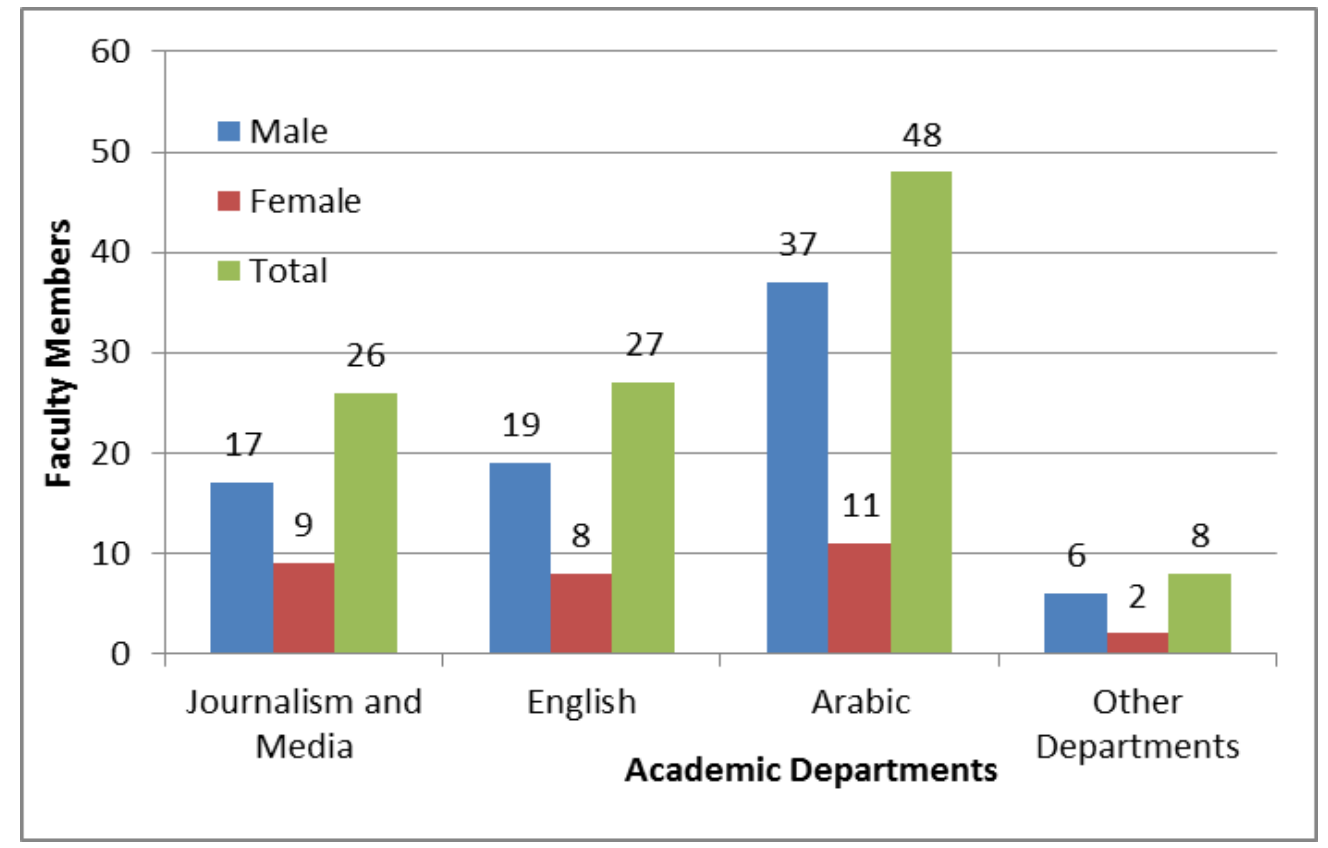

Figure 3. Influence of Gender on Blackboard Usage

\subsubsection{Age Group}

Results presented in Figure 4 illustrate the age groups of faculty members of each department, these differences are statistically significant. 


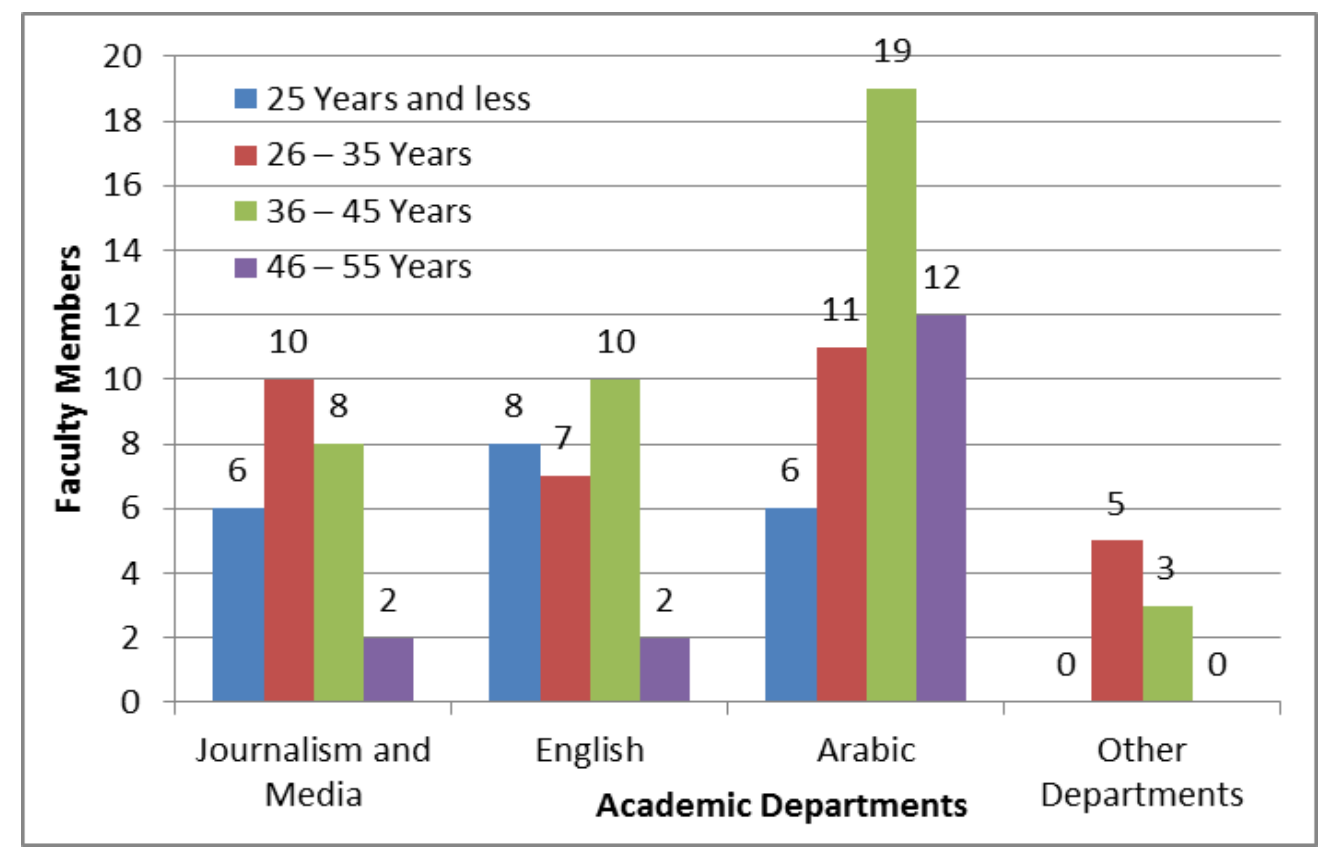

Figure 4. Influence of Age Group on Blackboard Usage

The figure 4 illustartes the overall number of faculty members with their age groups. One can expect that the difference is in favor of the second category (26-35 years old) and the third category (36-45 years old) as the numbers of faculty member's responses in these two categories are higher than in the other two categories. The difference between the third and fourth groups is also significant. So, it can be said that the third group (36-45 years) is the best in using Blackboard, followed by the second group (26-35 years), and thus, it can be concluded that age affects Blackboard usage. This can be explained by the fact that in general terms, older people use technology less frequently than the younger generation. However, in this research, the younger generation (those less than 25 years of age) are also, surprisingly, less frequent users of Blackboard - an amazing fact and divergent to expectation; this might be interpreted in such a way as to suggest that even though the younger ages may have the competencies and self-confidence to practice technology in overall they are, nevertheless, new to Blackboard and thus may not have the particular abilities for utilizing it in a viable manner.

\subsubsection{Professional Experience}

Results presented in Figure 5 illustrate the different categories of faculty member teaching experiences. The variation in experience is statistically important. It has been found that the faculty members with the 6 to 20 -year teaching experience (the two middle categories combined) appeared to use Blackboard more than both the first and the last categories. Hence, there has been an effect of professional experience on the use of Blackboard. This conclusion shows that young faculty members (here, less experienced) and older faculty members (here, those who have more than 20 years of teaching skills) use Blackboard less than the other middle categories. 


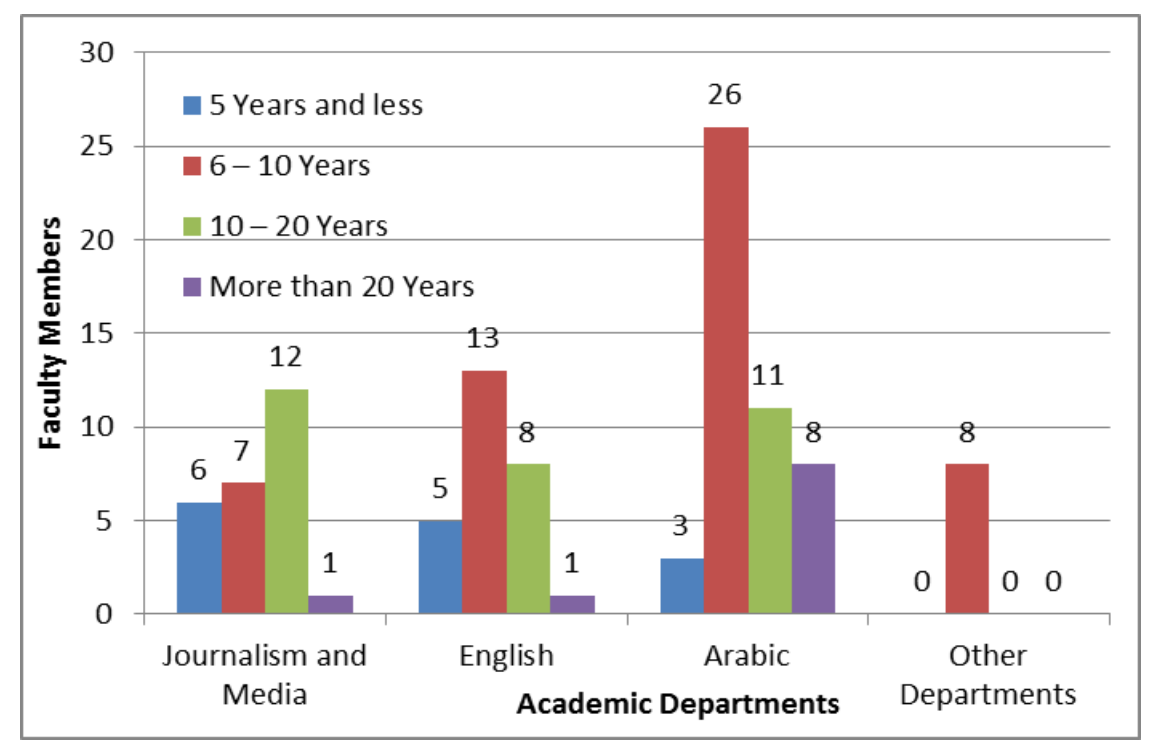

Figure 5. Influence of Professional Experience on Blackboard Usage

It is not surprising that the faculty members with over 20 years of Professional experience are not the prominent users of Blackboard in consideration that they were born before the emergence of the technology revolution. They tend to have their own teaching style and well-developed traditional teaching methods as well as strategies to which they tend to cling. It, nevertheless, seems to be less acceptable for a faculty member with around 5 years' experience to be not capable of embracing technology (LMS) in his or her teaching.

\subsubsection{Computer Literacy}

Results presented in Figure 6 illustrate the different categories of faculty member's computer proficiency.

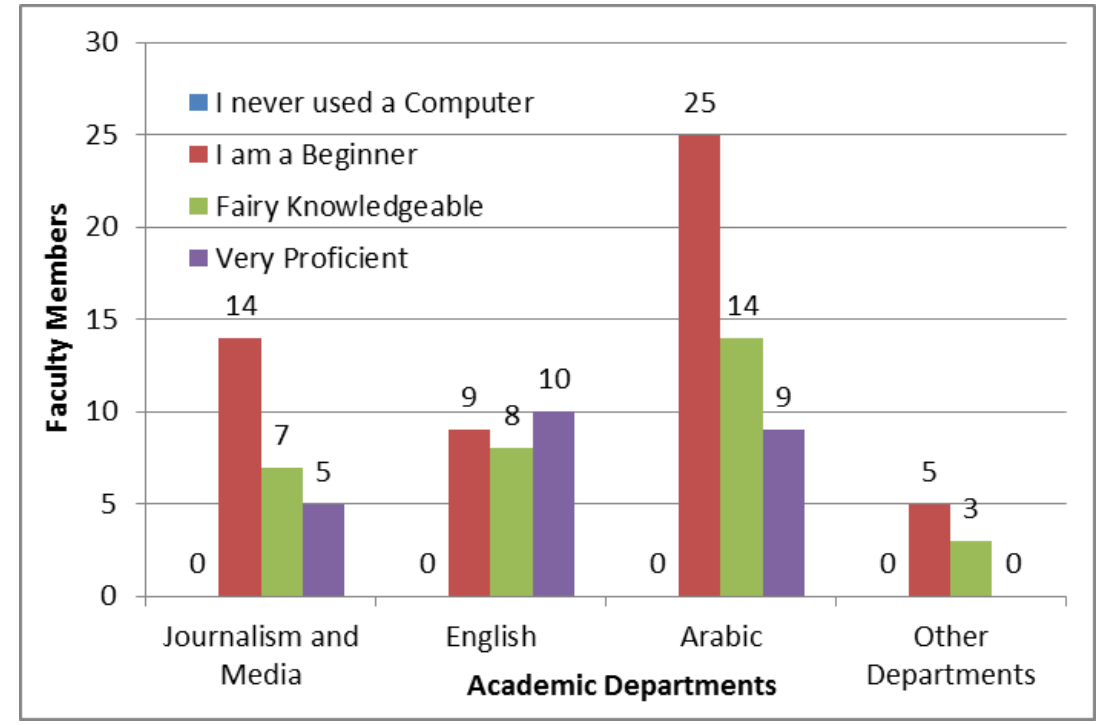

Figure 6. Influence of Computer Proficiency on Blackboard Usage

In higher education, where hi-tech developments have a transformational effect on learning and teaching, the expanded innovative proficiency among staff is of focal significance. The importance of teachers' ICT capabilities has been recognized in a number of countries, with many researchers arguing that "teachers need to be able to handle the 
technology with confidence". One of the primary methods of reasoning for the advancement of instructors' ICT-related abilities is the improvement of students' learning results and the advancement of their ICT proficiency. These statistics may be due to the fact that they are older than the digital natives and may not be open to adopting new technology automatically.

\subsubsection{Internet Access}

Results presented in Figure 7 illustrate the different locations of internet access to perform online lectures of the assigned courses.

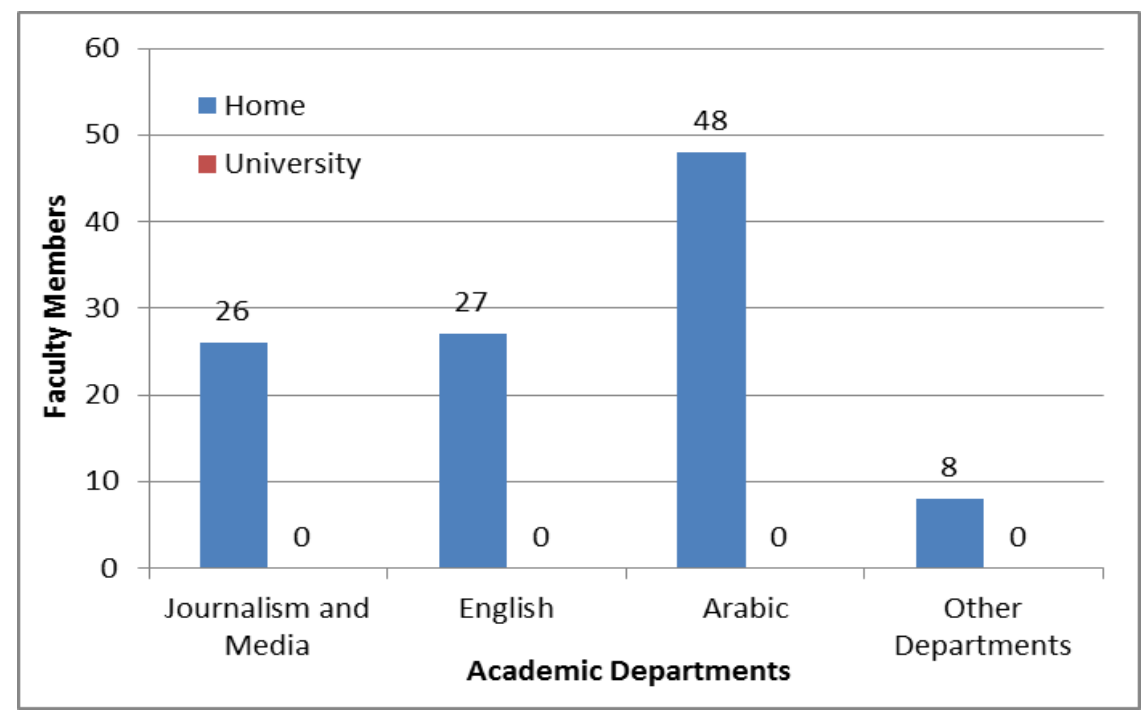

Figure 7. Influence of Internet Access on Blackboard Usage

Since Blackboard is an online tool which only works when the Internet is accessible, it is imperative to take note of the accessibility of the Internet for faculty members both in the university and outside. This study exposes that $100 \%$ of the faculty members of these departments can access the Internet from their home because all lectures are conducted in the evening time after office hours in $4-6 \mathrm{pm}, 6-8 \mathrm{pm}$, and $8-10 \mathrm{pm}$ sessions, because most of the students are doing their jobs in public and private organizations during morning time. This implies there is high accessibility of the Blackboard application whenever a faculty member wishes to utilize it.

\subsection{Utilization of Blackboard by Faculty Members}

This section explains the utilization of Blackboard by faculty members, which contains the following parameters: Frequency of Blackboard usage by faculty, Blackboard features used by faculty, Blackboard communication tools used by faculty, semester accomplishments, and Blackboard Support for faculty members. See Appendix for Figure 14, which illustrates the sample progress report of the LMS courses' lectures prepared by the program coordinator daily.

\subsubsection{Frequency of Blackboard Usage by Faculty}

The research work has shown that faculty members have been participating in the utilization of Blackboard frequently in their teaching process within the academic semester. Earlier training on Blackboard utilization was given to all faculty members during orientation sessions and they are completely mindful of the advantages of utilizing the learning management system (LMS). 




Figure 8. Frequency of Blackboard Usage by Faculty

The Blackboard utilization results proved that most of the faculty members use Blackboard to expedite their courses at least $2-3$ times each week, as illustrated in Figure 8.

\subsubsection{Blackboard Features Used by Faculty}

Training techniques need a range of instructional strategies that might empower and energize self-guided education.

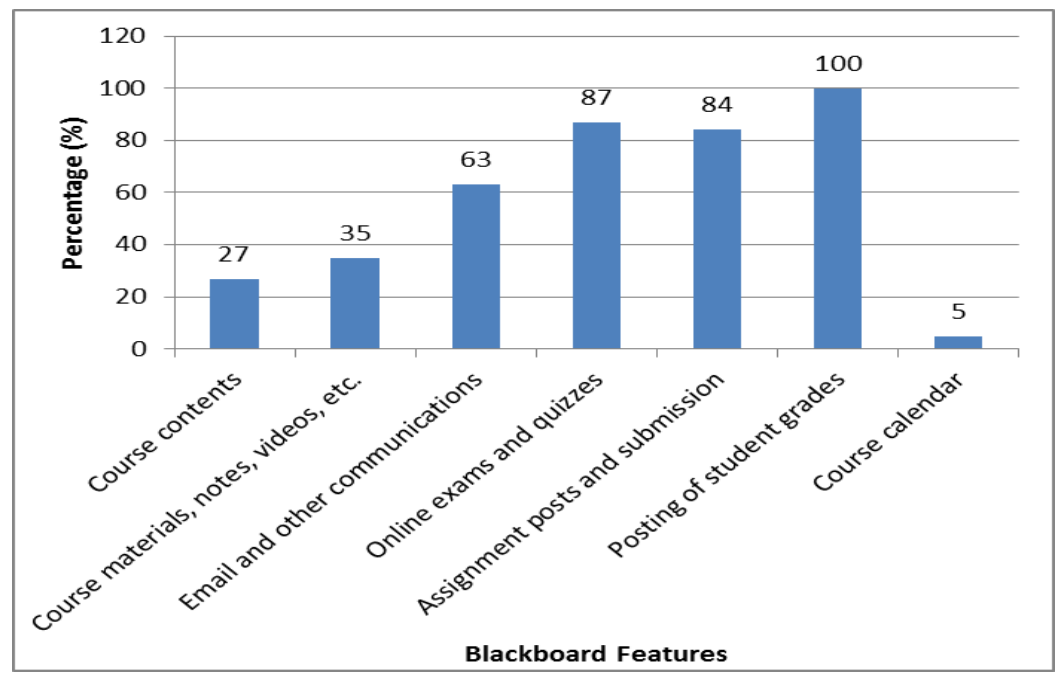

Figure 9. Blackboard Features Used by Faculty

Currently, e-learning platforms such as Blackboard are being used by educational institutions all over the world as part of their academic setting. For faculty members who use e-learning systems, computer knowledge is a positive predictor. Figure 9 illustrates how the faculty members classify the ways in which Blackboard is used in their courses. The majority of them used Blackboard to post course materials, grades, and assignments.

\subsubsection{Blackboard Communication Tools Used by Faculty}

Exploration supports the connection between personal association in online education and the learning that happens. While individuals within an online network direct their endeavors toward a common objective, strong associations are made. Students can accomplish this 
progressively through detailed discussions, robust relationships, and critical thinking in a network. Without an objective, associations, and discussions, there is no network.

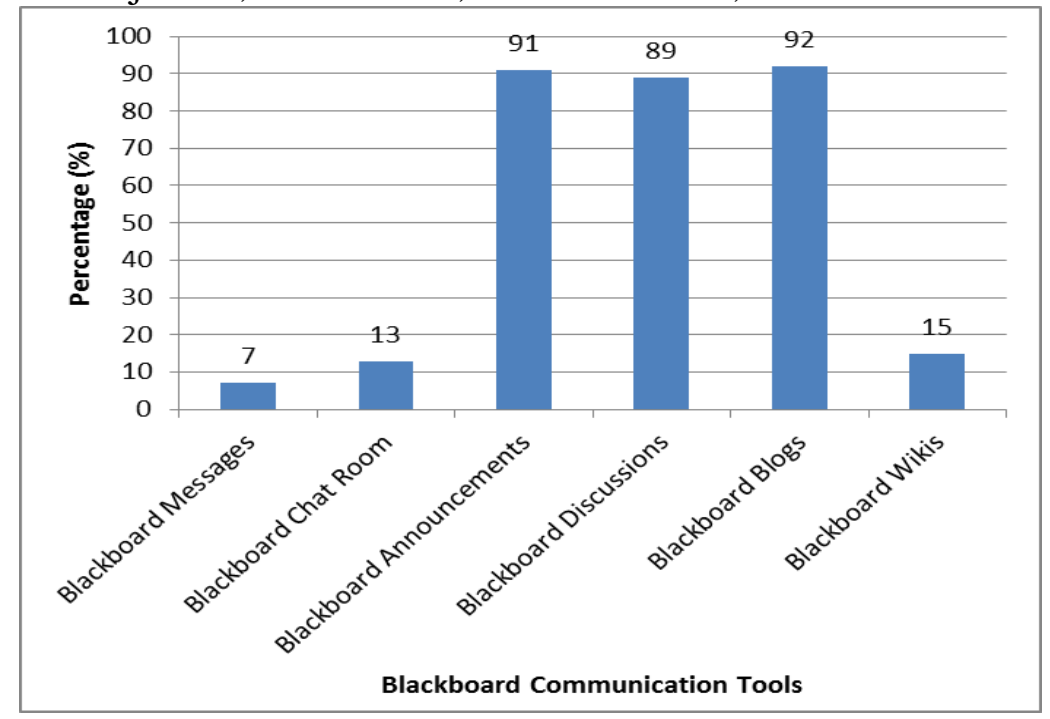

Figure 10. Blackboard Communication Tools Used by Faculty

In a productive web-based learning network, learners have the correct platforms for their face-to-face discussions. Blackboard Learn offers four specialized features for selfreflection, joint effort, and correspondence. The Blogs, Discussion Board, Journals, and Wikis tools permit to provide detailed assignments and assess students in authentic ways, where learners can share and make information. Figure 10 illustrates the communication tools which faculty members used on Blackboard during the academic semester.

\subsubsection{Semester Accomplishments by Faculty}

Results presented in Figure 11 illustrate the semester accomplishments of faculty members during the fall semester of the academic year of 2019/20.

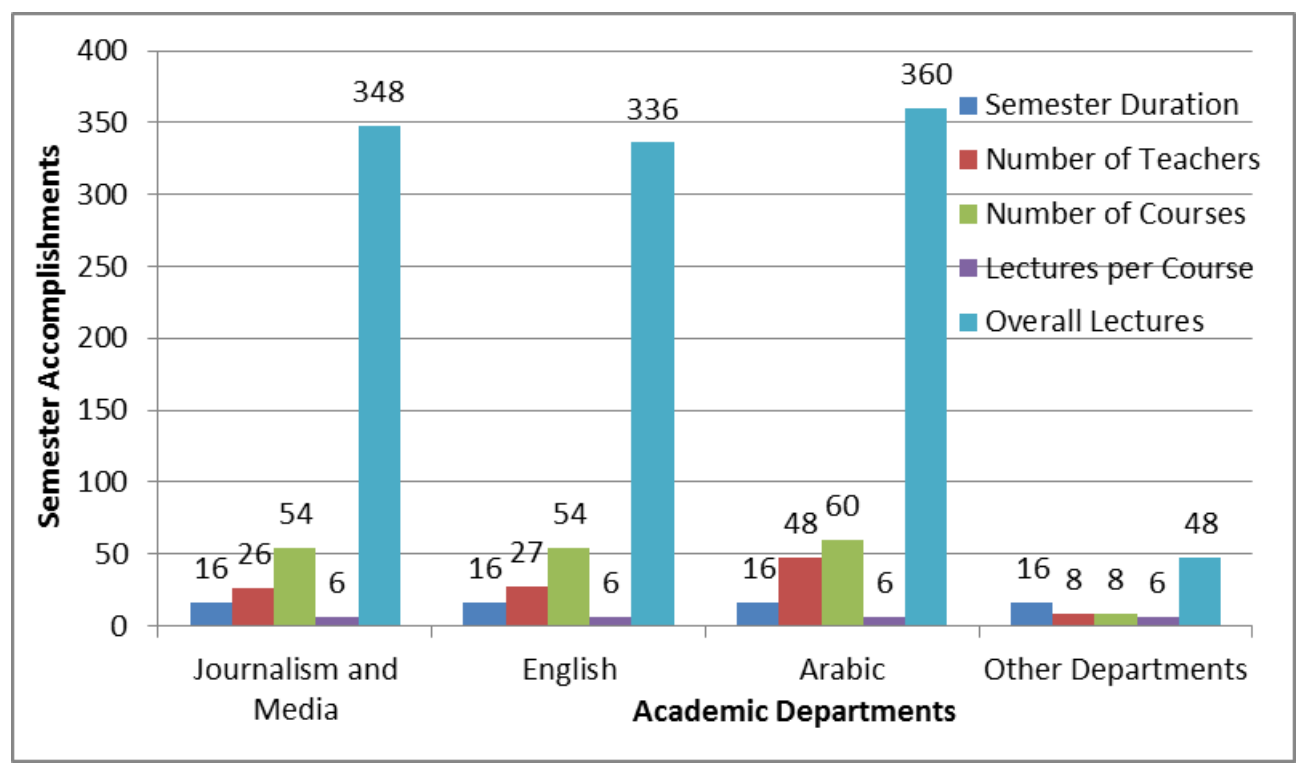

Figure 11. Semester Accomplishments by Faculty Members 
Each semester of the academic year has six alternative weeks of lectures and two weeks for final examination, the final examination is conducted within the campus. Total weeks of lectures including related activities (assignment, quiz, forms, and discussion) are twelve for both male and female students. Arabic department has more faculty members than the other departments because this department offered many courses during the semester. Every course has six alternative week lectures, one week is for males and another week for female students. English, Journalism, and Media departments completed 336 and 348 lectures respectively, because some courses have multiple groups with different times of lecture by the same faculty member.

\subsubsection{Blackboard Support for Faculty Members}

Differentiating two types of support that faculty needs to use Blackboard becomes important: technical support addressing the technical issues such as uploading class lists onto Blackboard, updating courses offered by faculty members toward the start of every semester, fixing server issues, and assistance for staff's specialized concerns. Another support is professional support, including helping faculty to use the different functions of Blackboard and to integrate this technology into their actual teaching. These forms of support are commonly prompted through short courses and workshops.

\subsection{Students Academic Performance with Blackboard}

The degree to which a student, teacher, or institution has accomplished its short or longterm educational objectives is academic success or "academic achievement". The social and economic development of the country is directly linked to student academic performance. The students' performance (academic achievement) plays an important role in producing the best quality graduates who will become great leaders and manpower for the country, thus responsible for the country's economic and social development.

During this study, the survey questionnaire asked 15 questions to consider the influence of Blackboard on the students' academic achievement. The number of participants who answered the questionnaire is illustrated in Table 3.

Table 3

\section{Participants of the Survey}

\begin{tabular}{|c|c|c|}
\hline Academic Term & Overall Students & Sample Size \\
\hline $2019-2020$ & 80 & 67 \\
\hline
\end{tabular}

All variables revealed during the content analysis and reliability testing fell into the static Blackboard, dynamic Blackboard, integrative Blackboard, and students' academic performance categories.

\subsubsection{Static Blackboard Practice}

The study suggested that to attain a high degree of self-discipline for Arts and Humanities students, the use of static Blackboard should be reduced. This is because faculty students are waiting for the teachers to post on Blackboard the solution key instead of completing the exercises themselves. Another finding is that students do no further homework to make their progress, so they focus exclusively on lecture notes, slides, and video clips posted for them. Table 4 illustrates the expected factors of static Blackboard.

Table 4

Static Blackboard Usage

\begin{tabular}{|c|l|}
\hline Taxonomy & Factors \\
\hline Static Blackboard & Insufficient self-discipline \\
\hline
\end{tabular}




\begin{tabular}{|l|l|}
\hline & Deficiency of the learning environment \\
\hline & Strong level of dependency on main solutions \\
\hline Lack of attendance in classes \\
\cline { 2 - 2 } & Better understanding by reading \\
\hline
\end{tabular}

Overall students, especially those at the lower level and taking introductory courses, should rely less on the use of static Blackboard because it makes them less likely to attend the lectures, and more likely to view the lecture slides on Blackboard. The findings show that the use of static Blackboard among students does not provide a favourable learning environment. A good learning ambiance is a source of success in education. Because of the limited possibilities for contact or conversation with other students and teachers, as well as delayed feedback from instructors, it is impossible to preserve or generate an effective learning environment using static Blackboard.

\subsubsection{Dynamic Blackboard Practice}

Findings suggest that it is more fitting for students to use dynamic Blackboard than static Blackboard. The study demonstrates that dynamic Blackboard advantages are: real-time knowledge access, fast reviews or instant marking, enhanced connectivity, and enhanced twoway experiences, favoring successful learning among students. Table 5 illustrates the expected factors of dynamic Blackboard.

Table 5

\section{Dynamic Blackboard Usage}

\begin{tabular}{|c|l|}
\hline \multicolumn{1}{|c|}{ Taxonomy } & \multicolumn{1}{c|}{ Factors } \\
\hline \multirow{4}{*}{ Dynamic Blackboard } & Knowledge is available in real-time \\
\cline { 2 - 2 } & Rapid and timely evaluation \\
\cline { 2 - 2 } & Enhanced connectivity \\
\cline { 2 - 2 } & Better bidirectional interactions \\
\cline { 2 - 2 } & Overall enhanced student performance \\
\hline
\end{tabular}

Students can use innovative Blackboard anytime and anywhere, they can access and review course materials and submit tasks online. This form of the Blackboard is very useful when it comes to transforming students into active learners who can articulate themselves openly when participating in the learning process.

\subsubsection{Integrative Blackboard Practice}

Through the online and integrated classroom conversations and problem-solving, the use of integrative Blackboard increases the fundamental level of comprehension. The findings show that integrative Blackboard means that students continue to engage in the classroom and become successful learners. Regarding the use of integrative Blackboard by students, the findings illustrate that teachers can teach using integrated Blackboard tools such as "Adobe Link Expert" and students can be inspired to attend coordinated online sessions. Table 6 illustrates the expected factors of integrative Blackboard.

Table 6

\section{Integrative Blackboard Usage}

\begin{tabular}{|c|l|}
\hline Taxonomy & \multicolumn{1}{c|}{ Factors } \\
\hline \multirow{2}{*}{ Integrative Blackboard } & Online sessions are synchronized \\
\cline { 2 - 2 } & Discussions and problem-solving are in \\
\hline
\end{tabular}




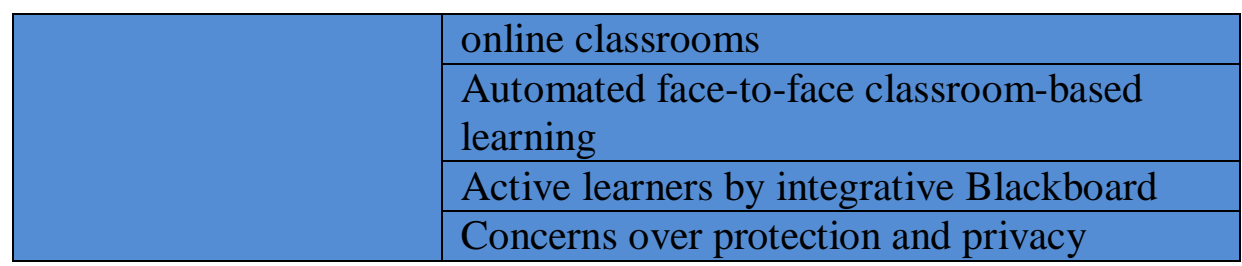

Students are usually with the use of integrative Blackboard online learning because it looks like structured, conventional face-to-face teaching. Finally, the students worry much about the extent of protection and privacy while using an integrative Blackboard, which is only available to students with a password. That indicates the level of confidentiality on integrative Blackboards.

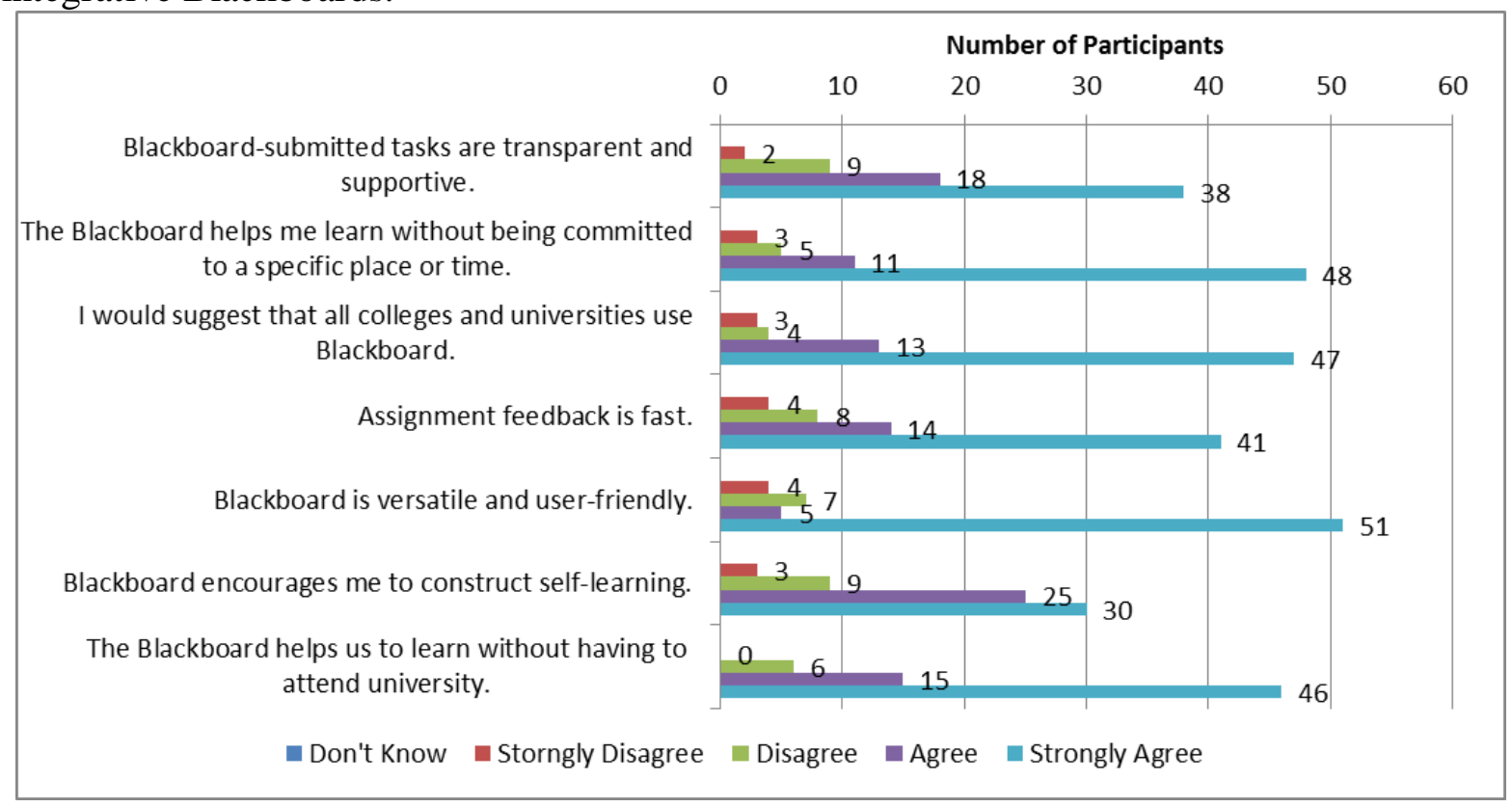

Figure 12. Satisfaction Level of Arts and Humanities Students

Figure 12 illustrates the students' attitudes and satisfaction level towards using the Learning Management System during learning. The study has illustrated that the majority of the students were fairly knowledgeable and proficient in computer literacy that is helpful for the adoption of an LMS.

\subsubsection{Analysis of Student Academic Performance}

Most of the research assessed the students' academic success using the final grades scored in the courses in question. Some research used GPAs (grade point average) to distinguish students doing well or not. We would not use certain quantitative or analytical data in this qualitative analysis to assess the students' success. Instead, we used qualitative methods to explain how during the courses the use of Blackboard led either to passing or failing. In particular, we followed the students' fundamental level of comprehension, the interpretation of the difficulty levels of the exams, students' enthusiasm in classes, the number of students seeking input in classes, and the extent of student involvement in the study. The factors of students' academic performance are illustrated in Table 7. 
Student Academic Performance

\begin{tabular}{|c|l|}
\hline Taxonomy & \multicolumn{1}{c|}{ Factors } \\
\hline \multirow{4}{*}{$\begin{array}{c}\text { Student Academic } \\
\text { Performance }\end{array}$} & Students' participation in the class \\
\cline { 2 - 2 } & Promptness of feedback \\
\cline { 2 - 2 } & Basic level of understanding is stronger \\
\cline { 2 - 2 } & Students' motivation \\
\cline { 2 - 2 } & Difficulty levels of examination \\
\hline
\end{tabular}

The report analyzed the students' academic success depending on the marks of the sessional appraisal; these marks are based on a mid-term examination, class participation, assessment of assignment and quizzes, discussion, and forums. Figure 13 illustrates a graph revealing the overall pass rate of the Faculty of Arts and Humanities students.

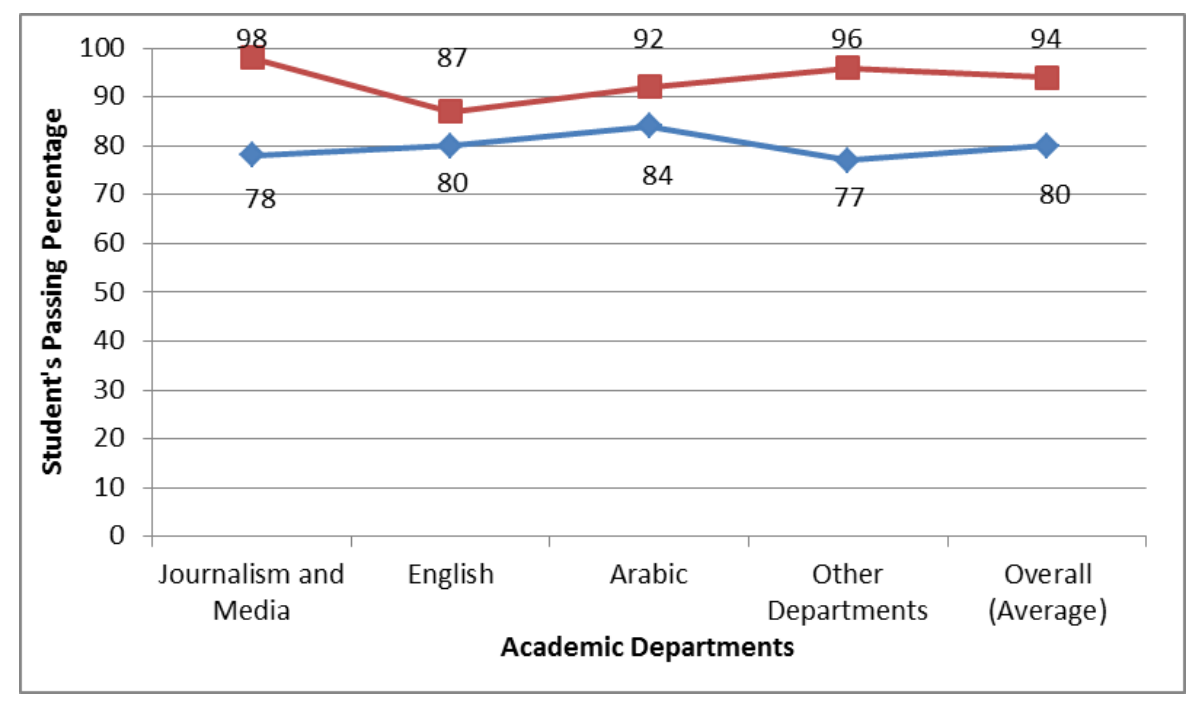

Figure 13. Analysis Graph of Students' Academic Performance

\section{CONCLUSION AND PROSPECTS FOR FURTHER RESEARCH}

The main objective of this study was to explore the Blackboard utilization by faculty members and the impact of Blackboard on academic performance within the Faculty of Arts and Humanities of Jazan University, Kingdom of Saudi Arabia. The Learning Management Systems manage the educational process electronically and provide an effective communication medium between the learner and instructor. Learning Management System is considered a strategic solution for planning, learning, and managing all aspects of learning in educational institutions.

Demographic variables of Gender have an affect on faculty use of the Blackboard. Age group, professional experience, and computer literacy contribute to statistically significant variations in the participants' responses, suggesting that Blackboard use differs among faculty members as a result of these demographic variables. This study has identified technology resources and infrastructure as the major factors leading to the limited use of Blackboard by faculty members in their courses. Another major constraint is related to the limited support and training for faculty members, the kind of support that would enable them to integrate this tool in their teaching. The results confirmed that the majority of faculty use Blackboard to facilitate their courses $2-3$ times per week. The faculty also utilize the major tools in the 
LMS including posting content (lecture notes, or PPT slides), online assessments and quizzes, communication methods, assignments, and posting of grades. The findings of this study illustrate the successful implementation of the learning management system at Jazan University. Results from the study illustrate that the use of Dynamic Blackboard and Integrative Blackboard is very suitable for all courses, considering the type and scope of challenging courses offered at the Faculty of Arts and Humanities. Based on the data gathered, the use of the various forms of Blackboard has a clear impact on learner's academic success. The study establishes that regular Blackboard interaction improves academic success among students. This study used course grades to assess how students did in their overall examinations as they consistently engaged during the learning period on Blackboard. The findings from this study are considered successful for teachers and students in terms of practical implications.

It is suggested that further research may focus on administrative and policy issues, including technical support, costs, upgradability, permissions and authorizations, and campus maintenance. The advice is that teacher preparation sessions on learning management systems should concentrate primarily on how the programs aim to enhance students' academic success and accomplish the expected learning outcomes. Higher education administration should give priority to appointing new faculty members who know how to use the Learning Management System in teaching.

\section{REFERENCES (TRANSLATED AND TRANSLITERATED)}

[1] J. Lever-Duffy, J. B. McDonald, \& A. P. Mizell, Teaching, and learning with technology. Boston, MA: Allyn and Bacon. 2003.

[2] A. G. Picciano, Distance learning: Making connections across virtual space and time. Upper Saddle River, NJ: Prentice-Hall. 2001.

[3] N. Sarkar, W. Ford, \& C. Manzo, "Engaging Digital Natives through Social Learning”. Systemics Cybernetics and Informatics, 15(2), 1-4, 2017.

[4] Moonsamy, Devraj \& Govender, Irene. "Use of Blackboard Learning Management System: An Empirical Study of Staff Behavior at a South African University". Eurasia Journal of Mathematics, Science and Technology Education. 14. 3069-3082. 2018.

[5] H. Montrieux, R. Vanderlinde, T. Schellens, \& L. De Marez, "Teaching and Learning with Mobile Technology: A Qualitative Explorative Study about the Introduction of Tablet Devices in Secondary Education. PLoS ONE, 10(12), e0144008, 2015

[6] Y.-T. Sang, K.-E. Chang, \& T.-C. Liu, "The effects of integrating mobile devices with teaching and learning on students' learning performance: A meta-analysis and research synthesis". Computers \& Education, 94, 252275, 2016.

[7] Muhammad Arshad, Shakeel Ahmad, Farhan Ahmad Siddiqui, "Social Media Technologies and their Benefits in Higher Education Institution: A Survey of Jazan University," Information Technologies and Learning Tools, 65(3), 91-102, 2018

[8] J. Demuyakor, "Coronavirus (COVID-19) and Online Learning in Higher Institutions of Education: A Survey of the Perceptions of Ghanaian International Students in China," Online Journal of Communication and Media Technologies, 10(3), 2020

[9] W. Ali, "Online and Remote Learning in Higher Education Institutes: A Necessity in light of COVID-19 Pandemic. Higher Education Studies, 10(3), 16-25, 2020

[10] S. Dhawan, "Online Learning: A Panacea in the Time of COVID-19 Crisis," Journal of Educational Technology Systems, 49(1), 5-22, 2020

[11] C. Rapanta, L. Botturi, P. Goodyear, L. Guàrdia \& M. Koole, "Online university teaching during and after the Covid-19 crisis: Refocusing teacher presence and learning activity," Postdigital Science and Education, 2(3), 923-945, 2020.

[12] J. Poon, "Blended Learning: An Institutional Approach for Enhancing Students' Learning Experiences," Merlot Journal of Online Learning and Teaching, 9(2), 271-288, 2013.

[13] I. Govender and M. Mkhize, "E-Learning in Place of Face-to-face Lectures: An Exploratory Study of Students' Perceptions. Alternation, 22(1), 183-203, 2015. 
[14] M. Arshad, A. Almuffarreh, K. M. G Noaman and M. N. Saeed, "Academic Semester Activities by Learning Management System during COVID-19 Pandemic: A Case of Jazan University," International Journal on Emerging Technologies, 11(5), 213-219, 2020

[15] I. Govender, \& D. Govender, “A constructivist approach to a programming course: Students' responses to the use of a Learning Management System," African Journal of Research in MST Education, 6(2), 238-252, 2012.

[16] A. Heirdsfield, "Blackboard as an online learning environment: What do teacher education students and staff think?," Australian Journal of Teacher Education, 36(7), 1-16, 2011.

[17] Al Busaidi Kamla and Al Shihi Hafedh, "Instructors' Acceptance of Learning Management Systems: A Theoretical Framework," Communications of the IBIMA, Vol. 2010, Article ID 862128, 10 pages, 2010.

[18] Aldiab, Abdulaziz, et al. "Utilization of Learning Management Systems (LMSs) in higher education system: A case review for Saudi Arabia." Energy Procedia 160, 731-737, 2019.

[19] A.S. Alzouman, N.A. Alhazzani, \& H. A. Alwaili, "The Effectiveness of Learning Management Systems (LMS) in Developing the Education and Upbringing Process". Information and Knowledge Management, 7, 21-27, 2017.

[20] R.F. Nyabawa, “Technology in Learning: Blackboard Usage and Its Impact on Academic Performance; a Case for Universities in Lesotho". International Journal of Humanities and Management Sciences (IJHMS), 4, 455461, 2016.

[21] S. A. Al-Naibi, K. B. Madarsha, \& N. A. Ismail, "Blackboard use by faculty members in the colleges of applied sciences in the Sultanate of Oman". International Journal for Innovation Education and Research, 3(4), 26-40, 2015.

[22] L. Lawson-Body, L. Willoughby, A. Lawson-Body, "Impact of The Use of Blackboard on Performance of Accounting Students". Issues in Information Systems, Volume 16, Issue II, pp. 209-216, 2015.

[23] Aldiab, Abdulaziz, et al. "Utilization of Learning Management Systems (LMSs) in higher education system: A case review for Saudi Arabia." Energy Procedia 160, 731-737, 2019.

[24] A. Chen, L. Li, X. Li, J. Zhang \& L. Dong "Study on Innovation Capability of College Students Based on Extenics and Theory of Creativity". Procedia Computer Science, 17, 1194 - 1201, 2013.

[25] V. Venkatesh, M. Morris, G. Davis, \& F. Davis, "User acceptance of information technology: Toward a unified view". MIS Quarterly, 27(3), 425-478, 2003.

[26] V. Venkatesh, J .Thong and X. Xu "Consumer acceptance and use of information technology: extending the unified theory of acceptance and use of technology". MIS Quarterly 36(1): 157-178, 2012.

[27] F. Davis, "Perceived Usefulness, Perceived Ease of Use, And User Acceptance of Information Technology", MIS Quarterly, Vol. 13, pp. 319-339, 1989.

[28] V. Venkatesh \& F. Davis, "A Theoretical Extension of the Technology Acceptance Model: Four longitudinal”, Management Science, vol. 46, no.2, pp. 186-204, 2000.

[29] P. Zhang, N. Li, \& H. Sun, “Affective Quality and Cognitive Absorption: Extending Technology Acceptance Research". Paper presented at The Hawaii International Conference on System Sciences, 2006.

Text of the article was accepted by Editorial Team 29.09.2020

\title{
ДОСВІД ВИКОРИСТАННЯ СИСТЕМИ УПРАВЛІННЯ НАВЧАННЯМ BLACKBOARD В ДЖАЗАНСЬКОМУ УНIВЕРСИТЕТI
}

\section{Мухаммад Аршад}

доктор філософії, доцент, декан факультету електронного навчання та інформаційних технологій Джазанський Університет, м. Джазан, Королівство Саудівська Аравія

ORCID ID 0000-0003-2832-8705

msarshad@jazanu.edu.sa

\begin{abstract}
Анотація. Залучення студентів до навчального процесу вже давно відбувається за допомогою таких традиційних інструментів, як-от: підручники, лекції, відео та групові заняття. Сьогодні заняття, об'єднані як на глобальному, так і на місцевому рівні, є метою інтелектуального освіти. Система управління навчанням (LMS) стала основним інструментом для всіх закладів вищої освіти i основним напрямком навчання через Інтернет. Значимість системи управління навчанням визначається iï роллю у створенні інструктивного та освітнього розвитку, тому вона вважається найбільш важливим новим інструментом електронного навчання. Згідно зі звітом Освітнього дослідного центру закладів вищої освіти США, майже $100 \%$ установ підвищення кваліфікації мають систему LMS. Крім цього, LMS використовують 85\% викладачів (3 них 56\% щодня), 83\% студентів бакалаврату. 56\% аспірантів використовують LMS практично на всіх курсах навчання. Система управління навчанням (LMS) на сьогодні стає не тільки важливим інструментом для більшості закладів вищої освіти, але також розглядається як рушійна сила онлайн
\end{abstract}


навчання. Blackboard Learning Management System - це технологічно вдосконалена навчальна платформа в контексті електронного навчання, призначена для вивчення використання Blackboard для підготовки, навчання та проведення іспитів. Мета даного дослідження - вивчення ефективності використання Blackboard Learning Management System, оцінювання академічної успішності студентів під час навчального процесу в Джазанському Університеті, Королівство Саудівська Аравія. Крім цього, протягом дослідження вивчалось, у який спосіб викладачі використовують функції та інструменти комунікації в системі управління онлайн навчанням для сприяння студентам у їх навчальній практиці, а також 3 метою надання їм необхідного матеріалу. Завдяки отриманим результатам очікується, що як викладачі, так і адміністратори зможуть більш ефективно розвивати середовище онлайн навчання. Автори сподіваються, що результати цього дослідження можуть стати значним стимулом для використання платформи Blackboard 3 метою підвищення академічної успішності студентів вищими навчальними закладами інших країн.

Ключові слова: електронне навчання; система управління навчанням; методи коллаборативного навчання; платформа Blackboard; використання Blackboard; член факультету; технології навчання студентів; заклад вищої освіти.

\section{ОПЫТ ИСПОЛЬЗОВАНИЯ СИСТЕМЫ УПРАВЛЕНИЯ ОБУЧЕНИЕМ BLACКВОАRD В ДЖАЗАНСКОМ УНИВЕРСИТЕТЕ}

\section{Мухаммад Аршад}

доктор философии, доцент, декан факультета электронного обучения и информационных технологий Джазанский Университет, г. Джазан, Королевство Саудовская Аравия

ORCID ID 0000-0003-2832-8705

msarshad@jazanu.edu.sa

Аннотация. Вовлечение студентов в учебный процесс уже давно происходит с помощью традиционных инструментов, таких как учебники, лекции, видео и групповые занятия. В настоящее время занятия, объединенные как на глобальном, так и на местном уровне, являются целью интеллектуального образования. Система управления обучением (LMS) стала основным инструментом для всех высших учебных заведений и основным направлением обучения через Интернет. Значимость системы управления обучением определяется ее ролью в создании инструктивного и образовательного развития, поэтому она считается наиболее важным новым инструментом электронного обучения. Согласно отчету Образовательного исследовательского центра высших учебных заведений США, почти 100\% учреждений повышения квалификации имеют систему LMS. Кроме этого, LMS используют 85\% преподавателей (из них 56\% ежедневно), 83\% студентов бакалавриата. $56 \%$ аспирантов используют LMS практически на всех курсах обучения. Система управления обучением (LMS) на сегодняшний день становится не только важным инструментом для большинства высших учебных заведений, но также рассматривается как движущая сила онлайн-обучения. Blackboard Learning Management System - это технологически усовершенствованная обучающая платформа в контексте электронного обучения, предназначенная для изучения использования Blackboard для подготовки, обучения и проведения экзаменов. Цель данного исследования - изучение эффективности использования Blackboard Learning Management System, оценивание академической успеваемости студентов во время учебного процесса в Джазанском Университете, Королевство Саудовская Аравия. Кроме этого, в течение исследования изучалось, каким образом преподаватели используют функции и инструменты коммуникации в системе управления онлайн обучением для содействия студентам в их учебной практике, а также предоставления им необходимого материала. Благодаря полученным результатам ожидается, что как преподаватели, так и администраторы смогут более эффективно развивать среду онлайн обучения. Авторы надеются, что результаты этого исследования могут стать значительным стимулом для других высших учебных заведений не только Королевства в использовании платформы Blackboard c целью повышения академической успеваемости студентов.

Ключевые слова: электронное обучение; система управления обучением; методы коллаборативного обучения; платформа Blackboard; использование Blackboard; член факультета; технологии обучения студентов; высшее учебное заведение. 


\section{Appendix}

\begin{tabular}{|c|c|c|c|c|c|c|c|c|c|c|c|c|c|c|c|c|c|c|c|}
\hline \multicolumn{20}{|c|}{ Daily Progress Report of Blackboard Learning Management System Male/Female } \\
\hline \multicolumn{20}{|c|}{ Academic Year 2019/2020 Fall Semester 2019} \\
\hline \multicolumn{6}{|c|}{ Faculty of Arts and Humanities } & \multicolumn{4}{|c|}{ Male Group : 27} & & & & \multicolumn{7}{|c|}{ Week: Wk $5,11 / 13 / 2019$, Tuesday } \\
\hline $\begin{array}{c}\text { Couse } \\
\cos 0\end{array}$ & Course Nane & $\begin{array}{l}\text { Number } d \\
\text { Students }\end{array}$ & $\begin{array}{c}\text { Lecture } \\
\text { Ooy }\end{array}$ & Teuchet Name & Dsto & $\begin{array}{c}\text { Aetual } \\
\text { Lectue line }\end{array}$ & $\begin{array}{l}\text { Lactien ONing } \\
\text { Outued Inis }\end{array}$ & Conpersubot & 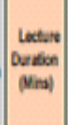 & $\begin{array}{l}\text { Sound } \\
\text { O.ality }\end{array}$ & $\begin{array}{l}\text { Vine } \\
\text { Cortet }\end{array}$ & $\begin{array}{l}\text { Ouit thet } \\
\text { Lecture }\end{array}$ & 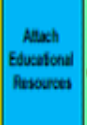 & 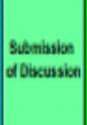 & $\begin{array}{c}\text { Overal } \\
\text { Lectures tii } \\
\text { Nisow }\end{array}$ & forum & $\begin{array}{c}\text { Militum } \\
\text { Enam }\end{array}$ & 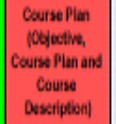 & Rensunkt \\
\hline $\sin x$ & 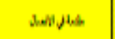 & $e$ & , & ansolomentwo & $11 / 4 / 2 / 00$ & $Y_{k}$ & $11 / 2 / 2,252 \pi$ & & 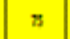 & $\cos$ & 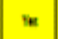 & Te & Ye & Ise & 3 & ko & Yes & Yes & \\
\hline$\Delta x$ & whivit & ut & , & visimp & $11 / 1 / 2 / 200$ & no & & & & & so & so & so & $\mathrm{N}_{\mathrm{z}}$ & 3 & No & in & $\mathrm{Yse}_{\mathrm{s}}$ & \\
\hline कin & thendidused & $e$ & $T$ &  & $11 / 1 / 200$ & $\bar{n}$ & & & & & $\bar{s}$ & $\mathrm{~S}_{0}$ & $\bar{P}_{\mathrm{B}}$ & $\mathrm{K}_{\mathrm{s}}$ & 4 & $Y_{n}$ & Yse & $Y_{s e}$ & \\
\hline Him & LEwidunto & $e$ & , & Antowish & $11 / 2 / 2000$ & no & & & & & so & The & Tet & so & 1 & hio & Yse & $Y_{s e}$ & \\
\hline $2+21$ & 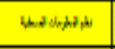 & ut & 1 & tyinmen & 11/1/2/mos & \begin{tabular}{|l|} 
Napitan in \\
minira| \\
\end{tabular} & 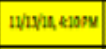 & & 0 & $\cos$ & so & res & Tet & Yse & 3 & No & $Y_{m e}$ & $v_{m e}$ & \\
\hline wail & 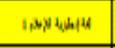 & in & 1 & Nimedivere & 12/12/300 &  & $12 / 4 / 1$, tass & & $n$ & $\cos d$ & 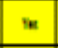 & Fe & Te & Yse & 3 & no & Yes & $\mathrm{Yes}_{\mathrm{s}}$ & \\
\hline halli & 2 insoluad 46 & h & 1 & Advindiajo & 11/4/200 & $Y_{n}$ & 11/4/4 saty & & 17 & and & $i n$ & Fes & $\mathrm{TeS}_{\mathrm{E}}$ & In & 4 & ho & $Y_{m e}$ & $Y_{M}$ & \\
\hline will & 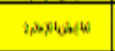 & \# & 1 & singen & $12 / 1 / 2 / 000$ & 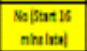 & 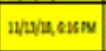 & & 8 & $\cos$ & $m$ & Fes & Th & Is & 3 & $\mathrm{Ym}_{\mathrm{m}}$ & Yse & Yes & \\
\hline Indil| & गुकाष & 5 & 165 & Damianont & & & & & & & & & & & & & & & \\
\hline Iकड़ा & 1916 & $i$ & 1 & Banveroser & & & & & & & & & & & & & & & \\
\hline  & 3016 & 9 & 1 & Bamponer & & & & & & & & & & & & 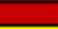 & . & & \\
\hline masis & Wusto & " & 1 & mathin & $11 / 1 / 2 / 200$ &  & 11/2/2/2, tนก & & $\infty$ & $\cos$ & $s$ & The & Ye & Yes & 3 & ho & Yse & $Y_{\mathrm{Se}}$ & \\
\hline hish & wis & in & 1 & 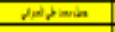 & 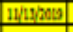 & $P_{m}$ & 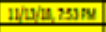 & & 28 & Cond & 5 & $N_{0}$ & $F_{t}$ & $\mathrm{~N}_{\mathrm{s}}$ & 4 & $Y_{m}$ & $Y_{m s}$ & $Y_{m}$ & \\
\hline haisi & $4 \%$ & 11 & 1 & seresial & 12/4/200 & 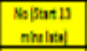 & 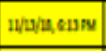 & & at & $\cos$ & s & $\mathrm{Ym}$ & Th & Yse & 3 & Yn & Yses & res & \\
\hline hasis & Letojestionj & is & 1 & Simpin & 12/12/300 & \begin{tabular}{|l|} 
Napanth \\
manira] \\
\end{tabular} & 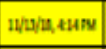 & & $\%$ & $\cos$ & $s$ & The & $\mathrm{Te}$ & Yse & 3 & Yn & Yse & $Y_{s e}$ & \\
\hline $\operatorname{sen}$ & swo in & $n$ & , & invisoinua & $12 / 1 / 2 / 200$ & Ye & $11 / 2 / 12, \cos \%$ & & $n$ & $\cos \theta$ & $s$ & res & $\mathrm{Yet}$ & No & 3 & Ko & Yes & Yse & \\
\hline Mastit & $4,4 \times V_{N}$ &  & 1 & intyation & \begin{tabular}{|l|l|l|l|}
$1 / 20$ \\
\end{tabular} & $\mathrm{Y}_{\mathrm{A}}$ & $11 / \mathrm{L} / \mathrm{L}, \mathrm{GOLN}$ & & $\bar{n}$ & $\cos d$ & 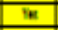 & $\mathrm{THE}_{\mathrm{H}}$ & $\mathrm{T}_{\mathrm{E}}^{\mathrm{E}}$ & Fis & 3 & ho & Yos & $P_{\mathrm{SE}}$ & \\
\hline ingitis &  & i6 & , & pistentar & 11/2/:aoso & Ye & $11 / 2 / 2,25 s / 4$ & & $a$ & $\cos$ & so & $\mathrm{Te}$ & $\mathrm{Te}$ & $\mathrm{ss}$ & 2 & $Y_{n}$ & 16 & $Y_{\mathrm{m}}$ & \\
\hline isyill &  & 8 & $I$ & Bmitions & & & & & & & & & & & & & & & \\
\hline Avelin & $\mid \mathrm{gld}$ & n & 1 & 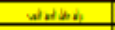 & \begin{tabular}{|l|l|}
$11 / 4 / 600$ \\
\end{tabular} & $P_{m}$ & 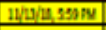 & & 197 & cond & 5 & $\mathrm{TES}_{\mathrm{B}}$ & $T_{t}$ & $I_{i s}$ & 3 & $Y_{m}$ & $Y_{m s}$ & $P_{m e}$ & \\
\hline $\log +132$ & spens & 3 & 1 & insianion w & 12/1/2/000 & 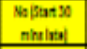 & 12/2/12, tson & & \& & $\cos d$ & $s$ & The & $\mathrm{Ten}$ & Yse & 3 & Yen & $\mathrm{Yes}$ & Yse & \\
\hline inemis & Whismed & $"$ & , & 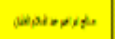 & $11 / 2 / 2000$ & $Y \mathrm{~m}$ & 11/2/4, assos & & is & $\cos$ & $\mathrm{s}$ & The & The & so & 3 & no & Yes & Yse & \\
\hline Avenies &  & " & 1 & vmingeto & $11 / 2 / 2000$ & \begin{tabular}{|c|} 
Salan in \\
minival \\
\end{tabular} & 12/12/2, ciore & & 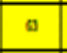 & $\cos \theta$ & $=$ & res & The & $Y_{k}$ & 4 & $Y_{n}$ & Yos & $Y_{\mu}$ & \\
\hline iverin & 69.4 & " & 1 & minumaxis & 12/1/200s &  & 12/4/מ, & & n & $\cos d$ & 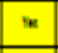 & No & Te & Tes & 7 & no & Yse & $Y_{m}$ & \\
\hline Aventil & | خد & * & 1 & (Whovenat & 11/2/2//ats & no & & & & & so & No & Te & $\mathrm{Ns}$ & 4 & hio & $\begin{array}{c}\text { No nod Quit } 1 \\
\text { allonst } \\
\text { portad }\end{array}$ & $\mathrm{Yse}_{\mathrm{s}}$ & \\
\hline & antinge & B. & I & amiatone & & & & & & & & & & & & & & & \\
\hline
\end{tabular}

Figure 14. Daily Progress Report of LMS Courses

This work is licensed under Creative Commons Attribution-NonCommercial-ShareAlike 4.0 International License. 